\title{
Personeli Güçlendirme Ve Örgütsel Vatandaşlık Davranışı Arasındaki İlişki: Bankacılık Sektöründe Bir Araștırma ${ }^{1}$
}

\author{
The Relationship Between Personnel Empowerment And Organizational Citizenship \\ Behavior: A Research In The Banking Sector
}

Özgül CAMGÖZ*

Zübeyir $B A \breve{G} C I^{* *}$

$\ddot{O} Z$

Bu araştırmanın amacı personel güçlendirme ile örgütsel vatandaşlık davranışı arasındaki ilişkiyi incelemektir. Bu amaçla özel bir bankanın Denizli ili ve ilçelerinde bulunan şubelerinde görev yapan toplam 200 banka personeli üzerinde bir araştırma gerçekleştirilmiştir. Veriler anket tekniği kullanılarak toplanmıştır. Dağıtılan anketlerden 176 tane geri dönüş sağlanmıştır. Hatalı ve eksik doldurma sonucu 4 adet anket geçersiz sayılmıştır. Anketlerin geri dönüş oranı \%86’dır. Banka personelinin personel güçlendirme algılarını ölçmek amacıyla Spreitzer (1995) tarafindan geliştirilen ölçek kullanılmıştır. Örgütsel vatandaşlık davranışının ölçümünde orjinali Vey ve Campbell (2004) ile Williams ve Shiaw (1999) tarafindan geliştirilen ve Basım ve Şeşen tarafindan (2006) geçerliliği ve güvenilirliği test edilmiş olan ölçekten yararlanılmıştır. Araştırmaya katılanların demografik özellikleri frekans ve yüzde analizleri ile incelenmiştir. Değişkenler arasındaki ilişkiyi belirlemek amacıyla korelasyon analizi yapılmıştır. Korelasyon analizi sonucunda personel güçlendirmenin alt boyutları ile örgütsel vatandaşlık davranışı alt boyutları arasında pozitif yönlü ve anlamlı bir ilişki olduğu belirlenmiştir.

\section{ANAHTAR KELIMELER}

Personel Güçlendirme, Örgütsel Vatandaşlık Davranışı, Banka Çalışanları

\begin{abstract}
The aim of this study is to examine the relationship between personnel empowerment and organizational citizenship behavior. For this purpose, a survey was carried out on 200 bank personnel working in the branches of a private bank located in Denizli and its districts. Data were collected by using questionnaire technique. 176 of the questionnaires were returned. As a result of incorrect and incomplete filling, 4 polls were considered invalid. The return rate of surveys is 86\%. The scale developed by Spreitzer (1995) was used to measure personnel empowerment perceptions of bank personnel. In the measurement of organizational citizenship behavior, the scale which was originally developed by Vey and Campbell (2004) and Williams and Shiaw (1999) and tested by Basim and Şeşen (2006) has been used. The demographic characteristics of the participants were examined by frequency and percentage analysis. Correlation analysis was performed to determine the relationship between the variables. As a result of the correlation analysis, it was determined that there was a positive and significant relationship between the sub-dimensions of personnel empowerment and the sub-dimensions of organizational citizenship behavior.
\end{abstract}

\section{KEYWORDS}

Staff Empowerment, Organizational Citizenship Behavior, Bank Employees

\begin{tabular}{|c|c|c|}
\hline \multicolumn{2}{|r|}{$\begin{array}{c}\text { Makale Geliş Tarihi / Submission Date } \\
23.01 .2019\end{array}$} & $\begin{array}{c}\text { Makale Kabul Tarihi / Date of Acceptance } \\
\text { 31.07.2019 }\end{array}$ \\
\hline Attf & $\begin{array}{l}\text { Camgöz, Ö. ve Bağcı, Z. (2019). P } \\
\text { Bankacılık Sektöründe Bir Araştırma. } \\
373 .\end{array}$ & $\begin{array}{l}\text { Ve Örgütsel Vatandaşlık Davranışı Arasındaki İlişki: } \\
\text { syal Bilimler Meslek Yüksekokulu Dergisi, } 22 \text { (2), 362- }\end{array}$ \\
\hline
\end{tabular}

\footnotetext{
${ }^{1}$ Bu çalışma birinci yazar tarafından hazırlanan yüksek lisans tezinden türetilmiştir

*Bilim Uzman1, ozgul_2006@hotmail.com, ORCID: 0000-0002-3074-9122

${ }^{* *}$ Doç.Dr., Pamukkale Üniversitesi, İktisadi ve İdari Bilimler Fakültesi, zbagci@ pau.edu.tr, ORCID: 0000-0001-7902-1485
} 


\section{GíRiş}

Rekabetin uluslararası bir boyut kazanması, küreselleşme, teknolojik gelişmeler ve müşteri beklentilerindeki değişim günümüz iş dünyasını yakından etkilemektedir. Değişim sürecinde toplumlar artık bilgi toplumu haline gelmiştir. Bilgi toplumunda bilginin kaynăg insandır. Örgütsel başarının temel unsuru nitelikli insan gücüdür. Değişimi gören ve değişime ayak uydurmaya çalışan örgütlerde benimsenen yeni yönetim anlayışlarında insan artık bir maliyet unsuru değil bir yatırım unsuru olarak görülmektedir.

Günümüz örgütlerinin temel ihtiyacı güçlendirilmiş ve örgütsel vatandaşlık davranışını gösteren bireylerdir. Bu bağlamda kendi yetenek ve yetkinliklerine inanan, kararlara katılan, inisiyatif alabilen, örgüt yararına gönüllü bir biçimde fazladan rol davranışında bulunan çalışanlar değişen iş dünyasında örgütlere rekabet avantajı sağlayarak başarılı bir biçimde varlıklarını sürdürmelerine yardımcı olurlar. Araştırmamıza konu olan bankacılık sektörü de değişen piyasa koşullarından oldukça etkilenmektedir. Müşteri beklentilerine kısa zamanda cevap verebilmek ve kaliteli hizmet sunabilmek bankacılık sektörü için oldukça önemlidir. Personel güçlendirme anlayışı ile yetkinin devredilmesi, personelin eğitilmesi ve geliştirilmesi, örgüt içinde etkin bir iletişim ağı kurulması, bilginin açık ve anlaşılır bir biçimde paylaşılması, personelin ortak bir amacı benimsemesi bankacılık sektöründe hızlı ve iyi bir hizmet sunulmasının ön koşulu haline gelmiştir. Güçlendirilmiş bir personelin davranışı olarak nitelendirilebilecek örgütsel vatandaşlık davranışı da bankacılık sektöründe benzer öneme sahiptir. İleri görev bilincine sahip, yardımlaşma kültürünü edinmiş, etki alanı genişlemiş, beklenenin ötesinde örgüt yararına fazladan rol davranışında bulunan, çözüm odaklı olan, risk alabilen banka çalışanları da diğer hizmet sektörlerinde olduğu gibi bu sektörde de başarıyı sağlamaktadır.

$\mathrm{Bu}$ çalışmanın amacı, personel güçlendirme ve örgütsel vatandaşlık davranışı arasındaki ilişkiyi incelemektir. $\mathrm{Bu}$ amaçla bankacılık sektöründe bir araştırma gerçekleştirilmiştir. Çalışmanın literatür incelemesi kısmında personel güçlendirme ve örgütsel vatandaşlık davranışı kavramları detaylı bir biçimde açılanmaya çalışılmıştır. Çalışmanın araştırma kısmında ise belirlenen amaç doğrultusunda toplanan veriler ilgili analizlere tabi tutularak elde edilen bulgular yorumlanmaya çalışılmıştır.

\section{KAVRAMSAL ÇERÇEVE}

$\mathrm{Bu}$ başlık altında çalışmada kullanılan iki değişken (personel güçlendirme ve örgütsel vatandaşlık davranışı) ile ilgili literatürdeki çeşitli kaynaklardan edinilen bilgilere yer verilmiştir.

\subsection{Personel Güçlendirme Kavramı}

Güçlendirme kavramının tam olarak anlaşılabilmesi için öncelikle güç kavramının ele alınmasında fayda vardır. Güç, başkalarını etkileyebilme, başkalarının davranışlarını istenilen doğrultuda yönlendirebilme şeklinde tanımlanabilmektedir (Bağcı ve Bursalı, 2011: 9). Güç, ayrıca fiziksel ve düşünsel olarak etkileyebilme yeteneği olarak da ifade edilebilir. Güç bireylerin karşılıklı ilişkileri sonucu ortaya çıkan bir kavramdır. Güç sahibi olmak demek istenilen sonuçları elde edebilmek için gerekli potansiyele sahip olmak demektir. Personel güçlendirme ise, personelin yaptığı işin sorumluluğunu alabilmesi için gerekli olan eğitimlerin verilmesi, takım ruhunun oluşturulması, güvene dayalı ilişkilerin oluşturulması, gerekli desteğin sağlanması ile personelin kendi yetki ve sorumluluklarını üstlenmesini sağlayan bir yönetim biçimidir (Akın, 2010:201). Personel güçlendirme çalışanlara güç vermek olarak ifade edilebilir. Çalışanlar sahip oldukları güç sayesinde kararlara katılırlar, sorumluluk alırlar ve rahatça işleri ile ilgili görüşlerini ve düşüncelerini açıklayabilirler. Bu nedenle katılımlı yönetim personel güçlendirmenin etkin bir biçimi olarak düşünülebilir. Personel güçlendirme ve katılım birbirini destekleyen ve geliştiren iki kavram olarak görülebilir.

Personel güçlendirme bireylerin daha güçlü hale gelmesini sağlamaktır. Bireylerin hiyerarşik bir düzende statü sahibi olarak değil, bireysel anlamda kendilerini güçlü hissetmelerini sağlamaktır. Personel güçlendirme ile bireylerin bilgi ve deneyimlerini arttırmak, kendilerine daha çok güvenmelerini ve diğer bireylerle güçlü bir iletişim kurmalarını sağlamak amaçlanmaktadır (Doğan ve Demiral, 2007: 284). Güçlendirme, çalışanların ödüllendirilmesi, bilgi ve gücün onlarla paylaşılması (Hales ve Klidas, 1998: 88), bireyin benlik saygısı, kontrol odağı ve bilgi miktarıyla yakından ilişkili bir kavramdır (Avey vd., 2008: 112). Güçlendirme genel olarak karar verme sürecinin genişletilmesi ve personele kararlara katılma yetkisinin verilmesi olarak ifade edilebilir. Personelin özerklik kazanabilmesi ve yetki sahibi olabilmesi amacıyla örgütler tarafindan onlara rehberlik edilmesi, gerekli olan bilgi ve becerilerle donatılmalarını sağlamaktır (Chiang ve Jang, 2008: 42).

İlgili literatür incelendiğinde personel güçlendirmenin genellikle dört boyutta incelendiğini görülmektedir. Bunlar; anlamlılık, yeterlilik, seçim ve etkidir (Mete vd., 2015; Bedük ve Tambay, 2014; Durrah vd., 2014; Wang ve Lee, 2009). 
Anlamlılık: Personelin yaptığı iş için harcadığı zamana ve enerjiye değecek bir iş yaptığına inanmasıdır. $\mathrm{Bu}$ şekilde personel değerli bir görevi yerine getirdiğine kendisini inandırır (Appelbaum ve Honeggar, 1998: 34). Bireysel değerlerin ve inançların personelin örgütsel sorumlulukları ve davranışları ile örtüşmesidir.

Yeterlilik: Personelin yaptığı işi en iyi şekilde yapabilme becerisine sahip olduğuna dair inancını ve kendisini yaptığ 1 iş için "yeterli" hissetmesini ifade etmektedir (Fettahlıoğlu ve Sünbül, 2015: 162). Başka bir deyişle yeterlilik bireylerin iş yerindeki görev ve sorumluluklarını ustaca ve kendilerinden beklenen biçimde gerçekleştirme kapasitesine sahip olduklarına dair inançlarıdır.

Seçim: Yetkinlik davranışının ustalığa dönüşmüş hali olarak tanımlanmaktadır. Bireyin işleri ile ilgili konularda inisiyatif kullanmasıdır. Başka bir ifade ile özerklik, iş ile ilgili sarf edilecek eforun, atılacak adımların ve kullanılacak yöntemlerin belirlenmesinde personelin karar mekanizması olmasıdır (Spreitzer vd., 1999: 512).

Etki: Personelin işin yapılış şekli, yönetimi ve elde edilen sonuçları etkileme derecesidir. Yani personelin işin amaçlarına ulaşması sırasında aldıkları özgün kararlar ile elde edilen sonuçlarda farklılık oluşturabilmelerini ifade eder (Akın ve Saruhan, 2016: 28).

Personel güçlendirme, personelin müşterilerle ilişkilerini etkileyen bir kavramdır. Müşterilerle doğrudan iletişimde bulunan personelin müşteri ilişkilerinde başarılı olabilmesi için örgütün amaçlarını iyi biliyor olması gerekmektedir. Örgütün amaçlarını benimsemiş bir personelin anlık kararlar alması kolaylaşmaktadır. Personel güçlendirme faaliyetleri sayesinde personelin etkili karar alma becerileri de gelişmektedir (Yatkın, 2009: 131). Yüz yüze iletişimin hâkim olduğu günümüz hizmet sektöründe güçlendirilmiş bir personel hem kendisine hem hizmeti satın alan müşteriye hem de örgütüne önemli katkılar sağlamaktadır.

\section{2. Örgütsel Vatandaşlık Davranışı}

Örgütsel vatandaşlık davranışının araştırılmaya başlandığı ilk yıllarda önemi ve etkisi gerektiği kadar anlaşılamamıştır. Ancak bu kavram zamanla merak edilmiş ve birçok alanda araştırmalara konu olmuştur. Başta insan kaynakları yönetimi olmak üzere pazarlama, iletişim, stratejik yönetim, askeri psikoloji, iktisat, liderlik gibi alanlarda da yaygın bir biçimde araştırılmıştır (Podsakoff vd., 2000: 514).

İşini severek yapan, örgütsel faaliyetlerde isteyerek bulunan, örgüte değer veren, örgüt çıkarlarını koruyan personel sayesinde değeri, önemi ve etkisi anlaşılan örgütsel vatandaşlık davranışı 1980'li yıllarda Organ ve arkadaşları tarafından kavramsallaştırılarak literatüre kazandırılmıştır (Karataş, 2015: 50). Böylece örgütsel vatandaşlık kavramının literatürdeki ilk kullanımını 1983 yılında Dennis Organ ve arkadaşları gerçekleştirmiştir. Denis Organ'ın "tatmin performans sağlar" ifadesi ile akademik çalışmalara konu olmaya başlamıştır (Bateman ve Organ, 1983: 588). Örgütsel vatandaşlık davranışı, örgütün biçimsel ödül sisteminde doğrudan ve açık bir biçimde tanımlı olmayan, örgütün etkin ve verimli çalışmasını sağlayan, isteğe bağlı oluşan davranışlardır. Personel kendi iş tanımının dışına çıkarak işe yeni başlayan meslektaşının uyum sürecine gönüllü olarak destek olmakta, onun sosyalleşmesine, diğer personelle iletişiminin gelişmesine yardımcı olmaktadır. Örgütsel vatandaşlık davranışı, fazladan rol davranışı veya prososyal davranış olarak da ifade edilmektedir (Şanal, 2013: 530). Örgütsel vatandaşlık davranışını diğer davranışlardan ayıran temel unsurlar vardır. Bu unsurlar; personelin bu davranışları doğrultusunda ödüllendirilmemesi veya cezalandırılmaması, personel tarafindan görev tanımlarının üzerinde ve örgütsel amaçları gerçekleştirmek amacıyla yapılması ve personelin isteğine bağlı olarak ortaya çıkmasıdır (Turnipseed, 2002: 2).

Literatürde örgütsel vatandaşlık davranışını oluşturan boyutlar konusunda bir fikir birliğine varılamamıştır. Örgütsel vatandaşlık davranışı ile ilgili yapılan araştırmalar incelendiğinde Organ (1988) tarafindan ortaya konulan ve genel olarak kabul gören beş alt boyuta sahip olduğu görülmektedir (Aydoğan ve Dinçer, 2017; Dash ve Pradhan, 2014; Aslan, 2008; Jahangir vd., 2004). Bu boyutlar diğergamlık (Özgecilik, altruism), nezaket (courtesy), centilmenlik (sportmenship) ve sivil erdem (civil virtue) şeklinde isimlendirilmiştir.

Diğergamlık/ ̈̈zgecilik: Özgecilik boyutu, örgüt içinde bireylerin karşıllk beklemeden birbirine yardımc1 olmaları, sorunların çıkmasını engellemek amacıyla gönüllü çaba göstermeleridir (Podsakoff vd., 2000: 518). Özgecilik, örgüt içinde bireylere yardım etmeyi amaçlayan davranışların tamamıdır.

Nezaket: Özgecilik boyutu problem ortaya çıtıktan sonra görülen davranışları ifade ederken nezaket boyutu herhangi bir problemin ortaya çıkmasını engellemeye yönelik davranışları ifade eder (Budak, 2015: 13). Başka bir ifade ile nezaket, personelin problem oluşturacak herhangi bir durumu saptaması, bu duruma çözüm önerilerinde bulunması veya problemin ortaya çıkmasına engel olmasıdır (Organ ve Lingl, 1995: 343). Özgecilik ve nezaket boyutları yardımseverlik temeline dayanmakta olup birbirine çok benzer kavramlar olarak görülse de, yardım etme eyleminin gerçekleştiği zaman iki boyut arasındaki farklılığı belirginleştirir (Çetinkaya ve Çimenci, 2014: 244). 
Vicdanlılık: Vicdanlılık örgütsel düzeni sağlayan kurallara uyma davranışıdır. Personelin kurallara uyma konusunda gayretli ve istekli olmasıdır. Vicdanlılık boyutu "kişisel gayret", "ileri görev bilinci" ya da "genel uyum" olarak da ifade edilmektedir (Mahmutoğlu, 2017: 51). Personelin, işlerini zamanında ve düzenli bir biçimde yürütmeleri, düzenli bir çalışma sistemi oluşturmaları, gün içerisinde verilen mola zamanlarını kurallara uygun biçimde kullanmaları ve işe vaktinde gelip vaktinde gitmeleridir (Yıldız, 2017: 85).

Sivil Erdem: Bu boyut literatürde "erdemli olmak", "örgütsel erdem", "örgütsel gelişmeye destek vermek", "örgütsel katılım" ve "örgütü koruma" gibi isimlerle de anılmaktadır. Örgütsel vatandaşlık davranışının sivil erdem boyutu personelin örgüte bağl1lıkları ve sorumluluk duyguları ile ilgilidir. Personelin örgüte ve örgütsel faaliyetlere ilgisi yüksek olup örgütsel çıkarları korumaktadırlar (Ulusoy ve Sarıçoban, 2017: 660).

Centilmenlik/Sportmenlik: Personelin örgüt içindeki düzeni bozacak, çatışmaya neden olacak düşünce ve davranışlardan uzak durması, ortaya çıkan problemleri büyütüp sürekli bunlardan söz etmekten kaçınması ve saygısızlık olarak değerlendirilebilecek davranışlardan uzak durması örgütsel vatandaşlık davranışının centilmenlik boyutunu oluşturmaktadır. Her örgütte ortaya çıkma olasılığı olan basit hataların görmezden gelinmesi, hoşgörülü bir biçimde ilişkilerin yürütülmesi centilmenlik boyutunda davrandığının bir göstergesidir (Salihoğlu, 2013: 303).

Örgüt yaşamının temel amaçlarından birisi bireysel ve örgütsel amaçların bir arada gerçekleştirilmesidir. Örgütsel vatandaşlık davranışı bireysel amaçların örgütsel amaçlara ve örgütsel amaçların da bireysel amaçlara ulaşmasını sağlamak suretiyle bireysel ve örgütsel amaçlar arasında dengeleyici bir rol üstlenir. Personelin sadakati, özverisi ve bağlılığı örgütsel başarıyı sağlayan en önemli unsurlardır.

\subsection{Personel Güçlendirme ve Örgütsel Vatandaşlık Davranışı Arasındaki İlişki}

Güçlendirilmiş personel ile örgütsel vatandaşlık davranışını sergileyen personelin özellikleri karşılaştırıldığında ortaya çıkan farklılıklar şu şekilde ifade edilebilir: Güçlendirilmiş personel işine önem veren, işine katkı sağlayan, sürekli öğrenen, gelişime açık olan, bilgi ve becerisi yüksek, işini sahiplenen, sorumluluk alan, öz güveni yüksek, kararlara katılan ve vizyon sahibi olan bireylerdir. Örgütsel vatandaşl1k davranışı sergileyen personel ise ileri görev bilinci olan, arkadaşlarına yardımcı olan, bilgi paylaşımı yapan, şikâyetlerden uzak kalan, çözüm odaklı olan, akıllı, risk alabilen ve değişimi destekleyenlerdir. Güçlendirilmiş ve örgütsel vatandaşlık bilincine sahip bireylerin davranışları biçimsel iş tanımlarının ötesinde ve örgüt performansına önemli ölçüde etki eden davranışlardır.

Modern yönetim uygulamalarında örgütsel başarının anahtarı gücün çalışanlarla paylaşılmasıdır. Örgütler, gücü çalışanlarına aktardıkları ölçüde başarılı olurlar. Müşteri istek ve ihtiyaçlarına en kısa sürede cevap vermek günümüz örgüt yapılarının temel amaçları arasında yer almaktadır. Karar verme yetkisinin alt kademelere devredilmesi söz konusu bu amaca ulaşılmasını sağlar (Akçakaya, 2010: 148). Yetki devri, güçlendirilmiş ve örgütü için fazladan rol davranışında bulunan bireyler ile mümkün olabilmektedir.

Personel güçlendirme işi en iyi bilen kişi o işi her gün yapan kişidir anlayışına dayanmaktadır. Yaptığı işi kendi bilgi ve becerisine güvenerek yapan, herhangi bir onaya ihtiyaç duymayan, örgütsel kaynakları kullanabilen kişiler güçlendirilmiş, örgütsel verimlilik için bireysel sorumluluk alabilen kişilerdir (Pekküçükşen, 2013: 135). Örgütsel vatandaşlık davranışı ise iş ve görev tanımları dışında kalan, herhangi bir ödül veya ceza sistemine tabii olmayan, personelin kendilerinden beklenen davranışların ötesinde gönüllü olarak davranışta bulunmalarıdır. Personel güçlendirme ve örgütsel vatandaşlık örgütün başarısında aktif rol alan, örgütler için yaşamsal öneme sahip olan iki kavramdır.

Psikolojik güçlendirme yaklaşımına göre, güçlendirilmiş personel örgüt içindeki faaliyetlerini bir gereklilik olarak görmez. Kendi sorumluluklarının üzerinde görevlerini yerine getirir. Güçlendirilmiş personelin yetkinlikleri artar. Etki alanı genişler. Örgütsel vatandaşlık davranışı göstermeye eğilimli olurlar. Böylece personel güçlendirme ve örgütsel vatandaşlık arasında ilişki meydana gelir (Yücel ve Demirel, 2012: 27).

İlgili litertaürde konuyla ilgili yapılan çalışmalar incelendiğinde birbirine benzer sonuçlar elde edildiği görülmektedir. Örneğin, Noori ve Azma (2013) tarafından Bojnour'da 5 farklı firmadan rastgele örnekleme yolu ile seçilmiş 123 çalışan üzerinde gerçekleştirilen çalışmada güçlendirme algısı ile örgütsel vatandaşlık davranışı arasında pozitif ve anlamlı bir ilişki olduğu belirlenmiştir. Yazarlar örgüt içi kararların kontrolü, akıcı bir bilgi paylaşımı ve dinamik bir yapının örgütsel vatandaşlık davranışı ile anlamlı bir ilişki gösterdiğini belirtmişlerdir. Yine bir başka çalışmada Cheasakul ve Varma (2016) öğretmenlerin öğretme isteğinin ve güçlendirmenin örgütsel vatandaşlık davranışı üzerindeki doğrudan veya dolaylı etkisini belirlemeyi amaçlamışlardır. Thailand 'daki özel bir üniversitede görev yapan 124 akademisyen üzerinde yürütülen çalışmada katılımcıların statüsünün, profesyonel anlamda gelişimlerinin, öz yeterliliklerinin, kararlara katılma oranlarının yüksek olması durumunda örgütsel vatandaşlık davranışında bulunma olasılıklarının da arttığı belirlenmiştir. Diğer taraftan çalışmada personel güçlendirmenin etkililik alt boyutu ile ÖVD arasında negatif 
bir ilişki olduğu tespit edilmiştir. Bu olumsuz ilişki yazarlar tarafından akademisyenlerin bilgi ve becerilerinin öğrencilerin hayatlarına ve çalıştıkları üniversiteye etki edebileceği ancak bunun aynı zamanda yönetime karşı bir etkisinin de olduğu anlamına gelmeyeceği şeklinde yorumlanmıştır. Bir başka çalışmada Wat ve arkadaşları (2005) eşitlik ve ilişki kalitesinin örgütsel vatandaşlık davranışını etkilediğini, güçlendirme ve yöneticilere olan güvenin de aracı bir rol üstlendiğini ifade etmişlerdir. Hong Kong'da bulunan 183 yatırım bankacılığ1 personeli ile yapılan araştırmada, güçlendirmenin personeli örgütsel vatandaşlık davranışı göstermeleri konusunda motive eden bir uygulama olduğuna vurgu yapılmıştır. Ayrıca personelin yaptıkları işleri anlamlı bulmaları durumunda nezaket davranışı gösterme eğiliminde oldukları, etkili olduklarını hissettiklerinde vicdanlılık davranışını daha fazla gösterdikleri ve yeterlilik algılarının örgütleri için daha fazla çaba sarf etmeleri ve kendilerini geliştirmelerinde etkili olduğu sonucuna ulaşılmıştır.

Ülkemizde gerçekleştirilen çalışmalarda da bir hayli ilginç bulgulara rastlanılmaktadır. Örneğin, Arda (2006) tarafından bankacılık sektöründe çalışan bir kısım personele yönelik güçlendirme çalışmalarını konu alan araştırma yerli sermayeli özel bir bankanın 108 orta düzey yöneticisi üzerinde gerçekleştirilmiştir. Araştırma neticesinde elde edilen bulgular söz konusu organizasyonda yenilikçilik yapılabilecek ortamın oluşturulamadığını, personelin kendi kararlarına göre sorunları çözemediğini, personele gereken yetkinin devredilmediğini, öğrenme araçlarının yeterli olmadığını, yönetimin motivasyon sağlama konusunda eksik kaldığını, personelin başarılarının yeterince ödüllendirilmediğini ve personele yeterince güven duyulmadığını göstermiştir. Başka bir çalışma Taşlıyan ve arkadaşları (2014) tarafından akademik personel üzerinde gerçekleştirilmiştir. Personel güçlendirmenin örgütsel bağl1lık ve örgütsel vatandaşlık davranışına etkisini inceleyen bu çalışmada personel güçlendirme boyutlarından anlam, serbesti, yetkinlik ve etki ile örgütsel vatandaşlık arasında anlamlı düzeyde pozitif yönlü ve zayıf bir ilişki olduğu tespit edilmiştir. Buna bağlı olarak akademisyenlerin işlerini anlamlı ve önemli görmeleriyle birlikte görevlerini nasıl yapacakları ve yürütecekleri konusunda özgür olabilmeleri durumunda ve bölüm içerisinde alınan kararlar üzerinde etki ve kontrollerinin artmasıyla birlikte kurumlarına karşı olan bağlılıklarında ve örgütsel vatandaşlık davranışlarında artış olacağ yönünde bir yorum getirilmiştir. Bir başka çalışma Ala (2010) tarafından personeli güçlendirmenin örgütsel vatandaşlık davranışı üzerindeki etkisinde etiksel davranışın rolünü belirlemek amacıyla gerçekleştirilmiştir. İki farklı özel firma üzerinde yürütülen çalışmada iki farklı model test edilmiştir. İlk model de personel güçlendirme ile ÖVD arasında herhangi bir aracı eklenmemiş, direkt etkisi incelenmiş ancak sonuç anlamlı çıkmamıştır. Bundan dolayı ikinci bir model kurularak bu ikinci modelde güçlendirmenin ÖVD üzerindeki doğrudan etkisi kaldırılarak yeniden analiz edilmiştir. Güçlendirme değişkeninin ÖVD üzerindeki etkisinin tamamıyla etik değer ve davranış değişkeni aracılığıyla sağlandığı sonucuna ulaşılmıştır.

Yukarıda bahsi geçen araştırma bulgularından yola çıkarak aşağıdaki hipotezler oluşturulmuştur;

$\mathrm{H}_{1}$ : Personel güçlendirmenin alt boyutları ile özgecilik davranışı arasında pozitif ve anlamlı bir ilişki vardır.

$\mathrm{H}_{2}$ : Personel güçlendirmenin alt boyutları ile nezaket davranışı arasında pozitif ve anlamlı bir ilişki vardır

$\mathrm{H}_{3}$ : Personel güçlendirmenin alt boyutları ile vicdanlılık davranışı arasında pozitif ve anlamlı bir ilişki vardır

$\mathrm{H}_{4}$ : Personel güçlendirmenin alt boyutları ile centilmenlik davranışı arasında pozitif ve anlamlı bir ilişki vardir

$\mathrm{H}_{5}$ : Personel güçlendirmenin alt boyutları ile sivil erdem davranışı arasında pozitif ve anlamlı bir ilişki vardır

\section{ARAŞTIRMANIN YÖNTEMI}

Araştırmanın amacı personel güçlendirme ile örgütsel vatandaşlık davranışı arasındaki ilişkiyi incelemektir. $\mathrm{Bu}$ amaç doğrultusunda özel bir bankanın Denizli ili ve ilçelerinde bulunan şubelerinde görev yapan toplam 200 banka personeli üzerinde bir araştırma gerçekleştirilmiştir. Veriler anket tekniği kullanılarak toplanmıştır. Dağıtılan anketlerden 176 tane geri dönüş sağlanmıştır. Hatalı ve eksik doldurma sonucu 4 adet anket geçersiz sayılmıştır. Anketlerin geri dönüş oran $\% 86$ 'dır.

Hazırlanan anket formu formu üç kısımdan ibarettir.

Birinci kısımda katılımcılara yaşlarını, cinsiyetlerini, medeni durumlarını, eğitim durumlarını ve çalışma sürelerini ifade edebilecekleri sorular sorulmuştur.

İkinci kısımda banka personelinin personel güçlendirme algılarını ölçmek amacıyla Spreitzer (1995) tarafından hazırlanan ölçek yer almaktadır. Birçok araştırmacı tarafından kullanılan bu ölçek 4 alt boyut ve toplam 12 maddeden oluşmaktadır. Ölçekte ele alınan personel güçlendirme boyutları; anlamlılık, yeterlilik, özerklik ve etkidir. Katılımcıların ölçeklere verecekleri cevapları ise 1: Kesinlikle katılmıyorum, 2: Katılmıyorum, 3: Kararsızım, 4: Katılıyorum, 5: Kesinlikle katılıyorum şeklinde beşli Likert ölçeğine göre düzenlenmiştir. Bu çalışmada ölçeğin toplam Cronbach alfa güvenilirlik katsayısı 0.874 olarak hesaplanmıştır. 
Üçüncü kısımda ise banka personelinin örgütsel vatandaşlık davranışını ölçmek amacıyla orjinali Vey ve Campbell (2004) ile Williams ve Shiaw (1999) tarafından hazırlanan ve Basım ve Şeşen tarafindan (2006) geçerliliği ve güvenilirliği test edilmiş olan ölçek bulunmaktadır. Bu ölçek Organ (1988) tarafından ortaya konulan ve birçok araştırmada kullanılan beş temel örgütsel vatandaşlık davranışı boyutunu ölçmektedir. Bu ölçekte özgecilik alt boyutunda 5 madde, vicdanl1lık alt boyutunda 3 madde, nezaket alt boyutunda 3 madde, centilmenlik alt boyutunda 4 madde ve sivil erdem alt boyutunda 4 madde olmak üzere toplamda 19 madde bulunmaktadır. Katılımcıların ölçeklere verecekleri cevapları ise 1: Kesinlikle katılmıyorum, 2: Katılmıyorum, 3: Kararsızım, 4: Katılıyorum, 5: Kesinlikle katılıyorum şeklinde beşli Likert ölçeğine göre düzenlenmiştir. Ölçeğin toplam Cronbach alfa güvenilirlik katsayısı bu çalışma için 0.925 olarak hesaplanmıştır

Araştırmada verilerin analizinde SPSS 16 paket programı kullanılmıştır. Araştırmaya katılanların demografik özellikleri frekans ve yüzde analizleri ile incelenmiştir. Araştırmada kullanılan ölçeklerin geçerliğinde faktör analizi, güvenilirliğinde ise Cronbach's Alpha iç tutarlılık katsayısı kullanılmıştır. Değişkenler arasındaki ilişkiyi belirlemek amacıyla korelasyon analizi yapılmıştır.

\section{BULGULAR}

\subsection{Demografik Özelliklere İlişkin Bulgular}

Katılımcıların demografik özelliklerine ilişkin dağılımları tablo 1'de sunulmuştur

Tablo 1: Katılımcıların Demografik Özelliklerine Göre Dağılımları

\begin{tabular}{|c|c|c|c|c|}
\hline & & Frekans & Yüzde & Kümülatif Yüzde \\
\hline \multirow{2}{*}{ Cinsiyet } & Kadın & 71 & 41,3 & 41,3 \\
\hline & Erkek & 101 & 58,7 & 100,0 \\
\hline \multirow{3}{*}{ Yaş } & 19-25 Yaş & 13 & 7,6 & 7,6 \\
\hline & 26-44 Yaş & 130 & 75,6 & 83,1 \\
\hline & 45-59 Yaş & 29 & 16,9 & 100,0 \\
\hline \multirow{2}{*}{ Medeni Durum } & Evli & 109 & 63,4 & 63,4 \\
\hline & Bekâr & 63 & 36,6 & 100,0 \\
\hline \multirow{3}{*}{ Eğitim Durumu } & Ön lisans & 41 & 23,8 & 23,8 \\
\hline & Lisans & 119 & 69,2 & 93,0 \\
\hline & Yüksek Lisans & 12 & 7,0 & 100,0 \\
\hline \multirow{6}{*}{ Çalışma Süresi } & 1 yıldan az & 13 & 7,6 & 7,6 \\
\hline & $1-5 \mathrm{y} 1 \mathrm{l}$ & 29 & 16,9 & 24,4 \\
\hline & 6-10 yil & 56 & 32,6 & 57,0 \\
\hline & $11-15$ yll & 51 & 29,7 & 86,6 \\
\hline & $16-20$ yil & 22 & 12,8 & 99,4 \\
\hline & 21 yıl ve üzeri & 1 & 0,6 & 100,0 \\
\hline
\end{tabular}

Tablo 1'e göre 172 kişilik örneklem grubunun \% 41,3'ü (71 kişi) kadınlardan oluşmaktadır. Katılımcıların çoğunluğunu \%75,6 ile (130 kişi) 26-44 yaş aralığındaki katılımcılar oluşturmaktadır. Bunu sırasıyla \%16,9 oranı ile (29 kişi) 45-59 yaş aralığındaki katılımcılar ve \%7,6 oranı ile (13 kişi) 19-25 yaş aralığındaki katılımcılar izlemektedir. Katılımcıların \%63,4'ünü oluşturan 109 kişi evlidir. Katılımcıların \%36,6'sını 
oluşturan 63 kişi ise bekârdır. Katılımcıların eğitim durumlarına göre dağılımlarına bakıldığında \%69,2'sinin(119 kişi) lisans mezunu, \%23,8'inin (41 kişi) ön lisans mezunu, \%7'sinin (12 kişi) yüksek lisans mezunu olduğu görülmektedir. Bu oranlardan anlaş1lacağı gibi katılımcıların çok büyük bir çoğunluğu lisans mezunudur. Katılımcıların kurumda çalıştıkları süreye göre dağılımlarına bakılırsa; \%7,6'sı (13 kişi) 1 yıldan az, \%16,9'u (29 kişi) 1-5 yıl arası, \%32,6'sı (56 kişi) 6-10 yıl arası, \%29,7'si (51 kişi) 11-15 yıl arası, \%12,8’i (22 kişi) 16-20 yıl arası ve son olarak \%0,6'sı (1 kişi) 21 yıl ve üzeri çalışma süresine sahiptir.

\subsection{Veri Toplama Araçlarının Geçerlik ve Güvenilirliği}

Araştırmada kullanılan ölçeklerin yapı geçerliliği için faktör analizinden güvenilirliği için de Cronbach's Alpha iç tutuarlılık katsayısından yararlanılmıştır.

Faktör analizi öncesinde eldeki veriler faktör analizi için uygunluk açısından incelenmiştir. Bunun için KMO değeri ile Barlett küresellik testi sonuçlarına bakılmıştır. Buna göre personel güçlendirme ölçeğinin KMO değerinin 0,879 ve Barlett testi sonucunun 2186,120 (p<0,000); örgütsel vatandaşl1k davranış1 ölçeğinin KMO değerinin 0,913 ve Barlett testi sonucunun 1705,466 ( $<<0,000)$ olduğu görüldüğünden eldeki verilerin faktör analizi uygulamaya elverişli olduğuna karar verilmiştir. Özdeğeri 1'den büyük olan faktörler ölçeğe dâhil edilmiş olup faktör yük değerleri için 0,40 alt sınır olarak belirlenmiştir. Yapılan faktör analizi sonucunda elde edilen faktörlerin sahip oldukları yükler ise tablo 2 'de yer almaktadır.

Tablo 2: Personel Güçlendirme ve ÖVD Ölçeklerinin Faktör Yükleri

\begin{tabular}{|c|c|c|c|c|c|c|c|c|c|}
\hline \multirow[b]{2}{*}{ MADDELER } & \multicolumn{9}{|c|}{ FAKTÖRLER } \\
\hline & Fak 1 & Fak 2 & Fak 3 & Fak 4 & Fak 5 & Fak 6 & Fak 7 & Fak 8 & Fak 9 \\
\hline Anlamlılık 1 & 0,810 & & & & & & & & \\
\hline Anlamlılık 2 & 0,845 & & & & & & & & \\
\hline Anlamlılık 3 & 0,882 & & & & & & & & \\
\hline Yeterlilik 1 & & 0,869 & & & & & & & \\
\hline Yeterlilik 2 & & 0,904 & & & & & & & \\
\hline Özerklik 1 & & & 0,852 & & & & & & \\
\hline Özerklik 2 & & & 0,869 & & & & & & \\
\hline Özerklik 3 & & & 0,864 & & & & & & \\
\hline Etki1 & & & & 0,656 & & & & & \\
\hline Etki 2 & & & & 0,816 & & & & & \\
\hline Etki 3 & & & & 0,792 & & & & & \\
\hline Özgecilik 2 & & & & & 0,510 & & & & \\
\hline Özgecilik 3 & & & & & 0,800 & & & & \\
\hline Özgecilik 4 & & & & & 0,704 & & & & \\
\hline Özgecilik 5 & & & & & 0,671 & & & & \\
\hline Vicdanlılık 1 & & & & & & 0,817 & & & \\
\hline Vicdanlılık 2 & & & & & & 0,625 & & & \\
\hline Vicdanlıl1k 3 & & & & & & 0,583 & & & \\
\hline Nezaket 1 & & & & & & & 0,601 & & \\
\hline Nezaket 3 & & & & & & & 0,985 & & \\
\hline Centilmenlik 1 & & & & & & & & 0,803 & \\
\hline Centilmenlik 2 & & & & & & & & 0,747 & \\
\hline Centilmenlik 3 & & & & & & & & 0,700 & \\
\hline Centilmenlik 4 & & & & & & & & 0,687 & \\
\hline Sivil Erdem 1 & & & & & & & & & 0,451 \\
\hline
\end{tabular}




\begin{tabular}{|c|c|c|c|c|c|c|c|c|c|}
\hline $\begin{array}{l}\text { Sivil Erdem } 2 \\
\text { Sivil Erdem } 3 \\
\text { Sivil Erdem } 4\end{array}$ & & & & & & & & & $\begin{array}{l}0,646 \\
0,768 \\
0,767\end{array}$ \\
\hline \multirow[t]{2}{*}{ Açıklanan Varyans (\%) } & 27,522 & 22,154 & 20,969 & 16,779 & 20,875 & 16,352 & 15,894 & 8,887 & 6,487 \\
\hline & \multicolumn{4}{|c|}{87,424} & \multicolumn{5}{|c|}{68,495} \\
\hline \multirow[t]{2}{*}{ Cronbach's Alpha $(\alpha)$} & 0,877 & 0,747 & 0,967 & 0,906 & 0,733 & 0,706 & 0,600 & 0,810 & 0,741 \\
\hline & \multicolumn{4}{|c|}{0,937} & \multicolumn{5}{|c|}{0,925} \\
\hline
\end{tabular}

Tablo 2 incelendiğinde personeli güçlendirme ölçeğinin literatürde geçen biçimiyle 4 faktörlü bir yapıya sahip olduğu ve bu faktörlerin birlikte toplam varyansın \%87'sini açıkladığ 1 görülmektedir. Anlamlılık faktörünün faktör yükleri 0,810 ile 0,882 arasında değişmekte olup açıkladığ toplam varyans \%27,522'dir. Yeterlilik faktöründe yer alan maddelerden biri faktör yükü alt sınırı olan 0,40 değerinden daha düşük bir değer aldığı için ölçekten çıkarılmıştır. Geriye kalan maddelerin faktör yükleri 0,869 ile 0,904'tür ve bu faktör toplam varyansın \%22,154'ünü açıklamaktadır. Özerklik faktörünün faktör yükleri 0,852 ile 0,869 arasında değişmektedir ve açıkladığ toplam varyans miktarı \%20,969'dur. Etki faktörünün faktör yükleri ise 0,656 ile 0,816 arasında değişmekte olup açıkladığı toplam varyans miktarı da \%16,779'dur. Yine aynı tabloya bakarak örgütsel vatandaşlık davranışları ölçeğinin de literatürde geçen biçimiyle 5 faktörlü bir yapıya sahip olduğu ve bu faktörlerin birlikte toplam varyansın \%68'ini açıkladığı söylenebilir. Özgecilik faktöründe yer alan maddelerden biri 0,40 değerinden daha düşük bir faktör yüküne sahip olduğu için ölçekten çıkarılmıştır. Geriye kalan maddelerin faktör yükleri 0,510 ile 0,800 arasında değişmektedir ve faktörün açıkladığı toplam varyans miktar1 \%20,875'tir. Vicdanlılık faktörünün faktör yükleri 0,583 ile 0,817 arasında değişmektedir ve açıkladığ 1 toplam varyans miktarı \%16,352'dir. Nezaket faktöründe yer alan maddelerden biri faktör yükü alt sınırı olan 0,40 değerinden daha düşük bir değer aldığı için ölçekten çıkarılmıştır. Geriye kalan maddelerin faktör yükleri 0,601 ile 0,985 'tir ve bu faktör toplam varyansın \%15,864'ünü açılamaktadır. Centilmenlik faktörünün faktör yükleri 0,687 ile 0,803 arasında değişmektedir ve açıkladığ faktörünün faktör yükleri ise 0,451 ile 0,768 arasında değişmekte olup açıkladığı toplam varyans miktarı da \%6,487'dir. Tüm bu sonuçlar dikkate alındığında kullanılan ölçeklerin geçerliliğe sahip olduğu söylenebilir.

Ölçeklerin güvenilirliği için Cronbach's Alpha iç tutarlılık katsayısına bakılmıştır. Güvenilirlik, katılımcıların araştırma kapsamında kendilerine sunulan ölçekteki maddelere verdikleri cevabın tutarlılık derecesidir. Güvenilirlik, ölçeğin ölçmek istenilen özelliği ne derecede doğru ölçtüğü ile ilgilidir (Büyüköztürk, 2017:181). Araştırmada kullanılan ölçeklerin güvenilirliğinin ölçülmesi için "Cronbach alfa" katsayıları hesaplanmıştır. Cronbach alfa katsayılarının alacağı değerler ve bu değerlere ilişkin yorumlar aşağıdaki gibidir (Kalaycı ve Diğerleri, 2005:405);

- $0,00<\mathrm{a}<0,40$ ise ölçek güvenilir değildir.

• $0,40<\mathrm{a}<0,60$ ise ölçek düşük güvenilirdir.

- $0,60<\mathrm{a}<0,80$ ise ölçek oldukça güvenilirdir.

- $0,80<\mathrm{a}<1,00$ ise ölçek yüksek derece de güvenilirdir.

Personel güçlendirme ölçeğinin genel Cronbach's Alpha değeri 0,937olarak hesaplanmıştır. Alt boyutların Cronbach's Alpha değerleri ise; anlamlılık boyutu için 0,877 , yeterlilik boyutu için 0,747 , özerklik boyutu için 0,967 , etki boyutu için 0,908 olarak hesaplanmıştır. Örgütsel vatandaşlık davranışı ölçeğinin Cronbach's Alpha değeri ise 0,925 olarak bulunmuştur. Örgütsel vatandaşlık davranışının alt boyutlarının Cronbach's Alpha değerleri özgecilik için 0,763 , vicdanl1lık için 0,706 , nezaket için 0,600 , centilmenlik için 0,810 ve sivil erdem için 0,741 olarak hesaplanmıştır.

\subsection{Personel Güçlendirme ve Örgütsel Vatandaşlık Davranışı Arasındaki Korelasyon Analizine İliş kin Bulgular}

Korelasyon analizi, sosyal bilimlerde en çok kullanılan analizlerden birisidir. Korelasyon analizinin amacı iki değişken arasındaki ilişkiyi ve söz konusu bu ilişkinin kuvvetini ve yönünü belirlemeye yöneliktir. Korelasyon kat sayısı -1 ile +1 aralığında değer almakta, bu değerler doğrultusunda ilişki yorumlanmaktadır. Korelasyon katsayısının +1 olması mükemmel bir pozitif ilişkiyi ifade ederken korelasyon katsayısının -1 olması mükemmel bir negatif ilişkiyi ifade eder. Korelasyon katsayısının 0,00 olması ise değişkenler arasında herhangi bir ilişkinin olmadığını ifade eder. Korelasyon analizindeki pozitif ilişki, değişkenlerden birine ait değerin artması durumunda diğer değişkene ait değerinin de artması anlamına gelir. Korelasyon analizindeki negatif ilişki ise değişkenlerden birine ait değerin artması durumunda diğer değişkene ait değerin azalmasını 
ifade etmektedir. Değişkenler arasındaki ilişkinin yorumlanmasında kolaylık sağlayacak değerler aşağıdaki gibidir (Büyüköztürk, 2017:32);

- $0,70<\mathrm{r}<1,00$ ise yüksek ilişki

- $0,70<\mathrm{r}<0,30$ ise orta düzeyde ilişki

- $0,30<\mathrm{r}<0,00$ ise düşük ilişki

Yapılan korelasyon analizi sonucunda elde edilen korelasyon katsayıları tablo 3’te verilmiştir.

Tablo 3: Personel Güçlendirme ve Örgütsel Vatandaşıık Davranışı Değişkenleri Arasındaki Korelasyon Analizine İlişskin Bulgular

\begin{tabular}{|c|c|c|c|c|c|c|c|c|c|}
\hline & $\mathbf{A}$ & $\mathbf{Y}$ & Ö & $\mathbf{E}$ & Ö & V & $\mathbf{N}$ & C & $\mathbf{S}$ \\
\hline A & 1 & & & & & & & & \\
\hline $\mathbf{Y}$ &, $580 * *$ & 1 & & & & & & & \\
\hline Ö &, $516^{* *}$ &, $644 * *$ & 1 & & & & & & \\
\hline $\mathbf{E}$ &, $519 * *$ &, $711 * *$ &, $816^{* * *}$ & 1 & & & & & \\
\hline Ö &, $591 * *$ &, $559 * *$ &, $358 * *$ &, $401 * *$ & 1 & & & & \\
\hline V &, $582 * *$ &, $510 * *$ &, $516 * *$ &, $532 * *$ &, $603 * *$ & 1 & & & \\
\hline $\mathbf{N}$ &, $527 * *$ &, $582 * *$ &, $431 * *$ &, $480 * *$ &, $608 * *$ &, $637 * *$ & 1 & & \\
\hline C &, $653 * *$ &, $687 * *$ &, $588 * *$ &, $605^{* *}$ &, $671 * *$ &, $728 * *$ &, $652 * *$ & & \\
\hline S.E. &, $535 * *$ &, $624 * *$ &, $536 * *$ &, $477 * *$ &, $648 * *$ &, $724 * *$ &, $679 * *$ &, $759 * *$ & 1 \\
\hline
\end{tabular}

**p<0,001; A (Anlamll1ık), Y (Yeterlilik), Ö (Özeklik), E (Etki), Ö (Özerklik), V (Vicdanlılık), N (Nezaket), C (Centilmenlik), S.E.( Sivil Erdem)

Tablo 3'te görüldüğü üzere personel güçlendirme alt boyutları ile örgütsel vatandaşlık davranış1 alt boyutları arasındaki ilişki şu şekilde özetlenebilir;

Personel güçlendirmenin anlamlılık, yeterlilik, özerklik ve etki alt boyutları ile örgütsel vatandaşlık davranışının özgecilik alt boyutu arasında pozitif yönde ve orta düzeyde anlamlı bir ilişki $(\mathrm{r}=0,591, \mathrm{r}=0,559$, $\mathrm{r}=0,358, \mathrm{r}=0,401, \mathrm{p}<0,01)$ olduğu belirlenmiştir. Buna göre araştırma kapsamında oluşturulan "personel güçlendirmenin alt boyutları ile özgecilik davranışı arasında pozitif ve anlamlı bir ilişki vardır" biçimindeki $\mathbf{H}_{\mathbf{1}}$ hipotezi doğrulanmış olmaktadır.

Personel güçlendirmenin anlamlılık, yeterlilik, özerklik ve etki alt boyutları ile örgütsel vatandaşl1k davranışının vicdanlılık alt boyutu arasında pozitif yönde ve orta düzeyde anlamlı bir ilişki $(r=0,582, r=0,510$, $\mathrm{r}=0,516, \mathrm{r}=0,532, \mathrm{p}<0,01)$ olduğu belirlenmiştir. Buna göre araştırma kapsamında oluşturulan "personel güçlendirmenin alt boyutları ile vicdanlılık davranışı arasında pozitif ve anlamlı bir ilişki vardır" biçimindeki $\mathbf{H}_{2}$ hipotezi doğrulanmış olmaktadır.

Personel güçlendirmenin anlamlılık, yeterlilik, özerklik ve etki alt boyutları ile örgütsel vatandaşlık davranışının nezaket alt boyutu arasında pozitif yönde ve orta düzeyde anlamlı bir ilişki $(\mathrm{r}=0,527, \mathrm{r}=0,582$, $\mathrm{r}=0,431, \mathrm{r}=0,480, \mathrm{p}<0,01$ ) olduğu belirlenmiştir. Buna göre araştırma kapsamında oluşturulan "personel güçlendirmenin alt boyutları ile nezaket davranışı arasında pozitif ve anlamlı bir ilişki vardır" biçimindeki $\mathbf{H}_{3}$ hipotezi doğrulanmış olmaktadır.

Personel güçlendirmenin anlamlılık, yeterlilik, özerklik ve etki alt boyutları ile örgütsel vatandaşlık davranışının centilmenlik alt boyutu arasında pozitif yönde ve orta düzeyde anlamlı bir ilişki $(\mathrm{r}=0,653$, $\mathrm{r}=0,687, \mathrm{r}=0,588, \mathrm{r}=0,605, \mathrm{p}<0,01)$ olduğu belirlenmiştir. Buna göre araştırma kapsamında oluşturulan "personel güçlendirmenin alt boyutları ile centilmenlik davranışı arasında pozitif ve anlamlı bir ilişki vardır" biçimindeki $\mathrm{H}_{4}$ hipotezi doğrulanmış olmaktadır.

Personel güçlendirmenin anlamlılık, yeterlilik, özerklik ve etki alt boyutları ile örgütsel vatandaşlık davranışının sivil erdem alt boyutu arasında pozitif yönde ve orta düzeyde anlamlı bir ilişki $(r=0,535, r=0,624$, $\mathrm{r}=0,536, \mathrm{r}=0,477, \mathrm{p}<0,01)$ olduğu belirlenmiştir. Buna göre araştırma kapsamında oluşturulan "personel 
güçlendirmenin alt boyutları ile sivil erdem davranışı arasında pozitif ve anlamlı bir ilişki vardır" biçimindeki $\mathbf{H}_{5}$ hipotezi doğrulanmış olmaktadır.

\section{SONUÇ}

Personel güçlendirmenin örgütsel vatandaşlık davranışı üzerindeki etkisini belirlemeye yönelik yapılan bu çalışma, özel bir bankanın Denizli ili ve ilçelerinde faaliyet gösteren şubelerinde çalışan 172 personel ile gerçekleştirilmiştir. Çalışma iki bölümden oluşmaktadır. Birinci bölümde personel güçlendirme ve örgütsel vatandaşlık davranışına ilişkin teorik bilgilere detaylı bir biçimde yer verilmiştir. İkinci bölümde ise araştırma kapsamında elde edilen veriler analiz edilmiş ve aşağıda özetlenecek olan sonuçlara ulaşılmıştır;

Bu çalışmada öncelikle kullanılan ölçeklerin literatürde ifade edilen yapıya uygunluğu test edilmeye çalışılmıştır. Bunun için ölçeklerin yapı geçerliği uygulanan açımlayıcı faktör analizi ile incelenmiştir. Yapılan faktör analizi neticesinde hem personeli güçlendirme ölçeğinin literatüre uygun bir şekilde dört faktörlü bir yapıya sahip olduğu (Spreitzer, 1995; Spreitzer vd., 1999; Laschinger vd., 2004; Tolay vd., 2012; Çelebi, 2009) hem de örgütsel vatandaşlık davranışı ölçeğinin literatüre uygun bir şekilde beş faktörlü bir yapıya sahip olduğu ( Arı, 2014; Bolat ve Bolat, 2008; Lo ve Ramayah,2009) belirlenmiştir.

Personel güçlendirme ile örgütsel vatandaşlık davranışı arasındaki ilişkinin derecesini ve yönünü belirlemek amacıyla Pearson Korelasyon Analizi yapılmıştır. Yapılan analiz neticesinde personeli güçlendirme alt boyutları (anlamlılık, yeterlilik, özerklik ve etki) ile örgütsel vatandaşlık davranışı alt boyutları (özgecilik, nezaket, vicdanlılık, centilmenlik ve sivil erdem) arasında pozitif yönlü anlamlı bir ilişki olduğu görülmüştür. Bu bulgu literatürdeki çalışma bulgularıyla paralellik arz etmektedir (Bektaş ve Karagöz, 2018; Çavuşoğlu ve Güler, 2017; Çavuşoğlu, 2016; Akgündüz vd., 2014; Taşlıyan vd., 2014; Noori ve Azma, 2013; Wat vd., 2005). Buradan yola çıkarak banka çalışanlarının harcadıkları zamana ve enerjiye değecek bir işe ve bu işi en iyi şekilde yapabilme becerisine sahip olduklarına inanmaları, iş ile ilgili sarf edilecek eforun, atılacak adımların ve kullanılacak yöntemlerin belirlenmesi sürecinde karar mekanizmasına dâhil olmaları ve işin yapılış şekli, yönetimi ve elde edilen sonuçlar üzerinde etki ve kontrollerinin artması durumunda bağlı oldukları örgüt yararına gönüllü bir biçimde fazladan rol davranışında bulunacaklarını söylemek mümkündür.

$\mathrm{Bu}$ araştırma bankacılık sektöründe gerçekleştirilmiştir. Bankacıllk sektörünün emek yoğun olması, personelin performans sistemine bağlı olarak çalışması, alt ve orta kademede çalışanların müşterilerle doğrudan iletişimde olmas1, eğitim ve geliştirme faaliyetlerinin son derece önemli olması ve yoğun rekabet ortamında benzer hizmeti veren bankaları birbirinden ayıran temel unsurun çalışan profili olması araştırmanın bu sektörde yapılmasında belirleyici olmuştur.

Personel güçlendirme personelin çabasını anlamlı kılan bir kavramdır. Personel güçlendirme ile personel kendilerini güçlendirilmiş hissederler böylece kendi rol tanımlarının ötesinde davranış sergilerler. Personelin kendi inisiyatifine bağlı olarak gönüllü bir biçimde gerçekleşen bu davranışlar literatürde örgütsel vatandaşlık davranışı olarak tanımlanmaktadır. Rekabetin giderek farklı bir boyut kazanması, teknolojinin her geçen gün gelişmesi, teknolojinin bireysel ve örgütsel yaşamın merkezinde olması, müşteri istek, şikâyet ve ihtiyaçlarının değişmesi, bu istek, şikâyet ve ihtiyaçlara kısa sürede cevap verme zorunluluğu yönetim anlayışlarında değişikliklere neden olmuştur. Günümüz koşullarına bağlı olarak değişim gösteren yönetim anlayışlarında örgütsel başarının temel prensibi gücün personelle paylaşılmasıdır. Gücün personelle paylaşıldığı, yetki devrinin verildiği, kararlara katılımın sağlandığı, düzenli geri bildirim sisteminin olduğu, eğitim ve geliştirmenin önemli olduğu örgütler başarılı olarak görülmektedir. Güçlendirilmiş personel yaptığ 1 işi anlamlı ve önemli görmektedir. İşlerini en iyi şekilde yapacak yeterliliğe ve yeteneğe sahip olduğuna inanır. Örgüt içindeki rollerini yerine getirirken inisiyatif alır, özgürce karar verip verdiği kararların sonuçlarını üstlenir ve örgütsel hedefler doğrultusunda gönüllü bir biçimde örgüt yararına fazladan rol davranışında bulunur. Dolayısıyla personelinden bu tür davranışlar bekleyen yöneticilerin personelini güçlendirecek uygulamalara yer vermesi büyük önem arz etmektedir.

$\mathrm{Bu}$ araştırmanın bulguları yalnızca uygulama alanı ile sınırlıdır, dolayısıyla tüm banka çalışanlarına genellenemez. Bu konuyla ilgili çalışma yapmak isteyen araştırmacıların çok daha geniş bir örneklem üzerinde çalışmaları önerilebilir. Ayrıca personel güçlendirmenin örgütsel vatandaşlık davranışı üzerindeki doğrudan ve başka değişkenler vasıtasıyla dolaylı etkisinin incelenmesinin de yararlı olacağı aşikârdır. 


\section{KAYNAKÇA}

Akçakaya, M., (2010). Örgütlerde uygulanan personel güçlendirme yöntemleri: Türk kamu yönetiminde personel güçlendirme, Karadeniz Araştırmaları Dergisi, (25),145-174.

Akgündüz, Y., Kale, A. ve Pazarbaşı, G. (2014). Futbol turizmine hizmet eden otel çalışanlarının psikolojik güçlendirme algılarının örgütsel vatandaşlık davranışlarına etkisi, Mustafa Kemal Üniversitesi Sosyal Bilimler Enstitüsü Dergisi, 11(28), 1-15.

Akın, A. ve Saruhan, S., (2016). Küçük ölçekli işletmelerde psikolojik güçlendirme ile örgütsel özdeşleşme arasındaki ilişkinin tespiti üzerine bir araştırma, Artvin Çoruh Üniversitesi Uluslararası Sosyal Bilimler Dergisi, 2(2),25-42.

Akın, M., (2010). Personeli güçlendirme algılaması, örgüt iklimi algılaması ve yaratıcı kişilik özelliklerinin örgüt düzeyinde yaratıı kişilik özelliklerinin örgüt düzeyinde yaratıcı çıtılar üzerindeki doğrudan ve dolaylı etkileri, Sosyal Bilimler Enstitüsü Dergisi, 29(2), 211-238.

Ala, Ş., (2010). Personeli güçlendirmenin, örgütsel vatandaşlık davranışı üzerindeki etkisinde etiksel davranışın rolü, Yüksek Lisans Tezi, Selçuk Üniversitesi, Sosyal Bilimler Enstitüsü, Konya.

Appelbaum, S. ve Honeggar, K., (1998). Empowerment: a contrasting overview of organizations in general ans nursing in particular an examination of organizational factors, managerial behaviors, job design, structural power, Empowerment in Organizations, 6(2):29-50.

Arda, S., (2006). Bankacılık sektöründe personel güçlendirme çalışmaları ve bir uygulama, Yüksek Lisans Tezi, Gazi Üniversitesi, Sosyal Bilimler Enstitüsü, Ankara.

Arı, G. (2014). Örgütsel Bağlılık, Örgütsel vatandaşlık davranışı ve işten ayrılma niyeti arasındaki ilişki: 4 ve 5 yıldızlı otel uygulaması, Yüksek Lisans Tezi, Adnan Menderes Üniversitesi Sosyal Bilimler Enstitüsü, Aydın.

Aslan, Ş. (2008). Örgütsel vatandaşlık davranışı ile örgütsel bağlılık ve mesleğe bağl1lık arasındaki ilişkilerin araștırılması, Yönetim ve ekonomi, 15(2),163-178.

Avey, J.B. , Hughes, L.W. , Norman, S.M. ve Luthans, K. (2008). Using positivity, transformational leadership and empowerment to combat employee negativity. Leadership and Organization Development Journal, 29(2), 110126.

Aydoğan, E. ve Dinçer E., (2017). Örgütsel iklim ve örgütsel vatandaşlık davranışı arasındaki ilişki: kalkınma bakanlığı örneği, Gazi Üniversitesi Sosyal Bilimler Dergisi, 9, 48-66.

Bağcı, Z. ve Bursalı, Y.M., (2011), Yöneticilerin güç kaynaklarının çalışanların örgüte bağlılıkları üzerine etkisi: çalışanların algılamalarına bağımlı analitik bir inceleme', Pamukkale Üniversitesi Sosyal Bilimler Enstitüsü Dergisi, 9, 9-21.

Basım, H. Nejat ve Şeşen, Harun (2006). Örgütsel vatandaşlık davranışı ölçeği uyarlama ve karşılaştırma çalışması. Ankara Üniversitesi Siyasal Bilgiler Fakültesi Dergisi, 61(4), 83-102.

Bateman, T.S. ve Organ, D.W. (1983). Job satisfaction and the good soldier: the relationship between affect and employee: citizenship, Academy of Management Journal, 26(4), 587-595.

Bedük, A. ve Tambay, A. (2014). Personel güçlendirme (empowerment) ve itibar yönetimi ilişkisi: bankacıllk sektöründe bir alan çalışması. Akademik Sosyal Araştırmalar Dergisi, 2(8), 319-338.

Bektaş, M. ve Karagöz, Ş. (2018). Algılanan güçlendirmenin çalışanların performans ve örgütsel vatandaşlık davranışları üzerine etkisi, Sosyal Araştırmalar ve Davranış Bilimleri Dergisi, 4(5), 31-46.

Bolat, O. ve Bolat, T. (2008). Otel işletmelerinde örgütsel bağlılık ve örgütsel vatandaşlık davranışı ilişkisi, Balıkesir Üniversitesi Sosyal Bilimler Enstitüsü Dergisi, 11(19), 75-94.

Budak, G., (2015). Psikolojik dayanıklılık ve örgütsel adalet algısının örgütsel vatandaşlık davranışı üzerine etkisi, Yüksek Lisans Tezi, Başkent Üniversitesi Sosyal Bilimler Enstitüsü, Ankara.

Büyüköztürk, S.., (2017). Sosyal Bilimler için Veri Analizi El Kitabı, (Pegem Yayıncılık, Ankara).

Chesakul, U. ve Varma, P., (2016). The influence of passion and empowerment on organizational citizenship behavior of teachers mediated by organizational commitment, Contaduria Administracion, 61, 422-440.

Chiang, C.F. ve Jang, S., (2008). The antecedents and consequences of psychological empowerment: the case of taiwan's hotel companies, Journal of Hospitality \& Tourism Research, 32(1), 40-61.

Çavuşoğlu, F. (2016). Psikolojik güçlendirmenin örgütsel vatandaşlık davranışı üzerindeki etkisi: izmir il merkezindeki beş yıldızlı konaklama işletmelerinde bir araştırma. Yüksek Lisans Tezi, Kâtip Çelebi Üniversitesi, İzmir.

Çavuşoğlu, F. ve Güler, M.E. (2017). Psikolojik güçlendirme ile örgütsel vatandaşlık davranışının ilişkisi ve demografik değişkenlere göre farklılıkları: izmir şehir merkezindeki konaklama işletmelerinde bir araştırma. Seyahat ve Otel İşletmeciliği Dergisi, 14 (2), 47-64.

Çelebi, M.A. (2009). Örgütsel bağlılı̆̆ı sağlanılmasında bir araç olarak personel güçlendirme, Yüksek Lisans Tezi, Karamanoğlu Mehmetbey Üniversitesi Sosyal Bilimler Enstitüsü, Karaman.

Çetinkaya , M. ve Çimenci, S., (2014). Örgütsel adalet algısının örgütsel vatandaşlık davranışı üzerindeki etkisi ve örgütsel özdeşleşmenin aracılık rolü: yapısal eşitlik modeli çalışması, Yönetim Bilimleri Dergisi, 12(23),244-246.

Dash, S. ve Pradhan, R., (2014). Determinants \& consequences of organizational citizenship behavior: a theoretical framework for indian manufacturing organisations, International Journal of Business and Management Invention, $3(1), 17-27$.

Doğan, S. ve Demiral, Ö., (2007). İşletmelerde personel güçlendirme kültürünün yaratılmasıyla müşteri memnuniyetinin sağlanması, Selçuk Üniversitesi Karaman İ.İ.B.F. Dergisi, 12(9), 283-284. 
Durrah, O., Khdour, N., l-Abbad, S. ve Saif, N. (2014). The impact of psychological empowerment on the effectiveness of job performance: a field study on the jordanian private banks, European Journal of Business and Management, 6(32), 176-189.

Fettahlığlu, O. ve Sünbül, M., (2015). Duygusal zekânın psikolojik güçlendirme üzerindeki etkisi, Akademik ve Sosyal Araştırmalar Dergisi, 3(14), 157-175.

Hales, C., ve Klidas, A., (1998). Empowerment in five-star hotels: choice, voice or rhetoric?, international Journal of Contemporary Hospitality Management, 10(3), 88-95.

Jahangir, N., Akbar, M.M. ve Haq, M. (2004). Organızatıonal citızenshıp behavıor: its nature and antecedents, BRAC University Journal, 1(2), 75-85.

Kalaycı, Ş., (2005). SPSS Uygulamalı Çok Değişkenli İstatistik Teknikleri, 1.b.,(Asil Yayın Dağıtım, Ankara).

Karataş, A., (2015). Örgütsel iklimin örgütsel vatandaşlık davranışına etkisi: bursa ilinde bir araştırma, Çukurova Üniversitesi İktisadi ve İdari Bilimler Fakültes Dergisii, 19(1), 47-58.

Laschinger, H. vd., (2004). A Longitudinal analysis of the impact of workplace empowerment on work satisfaction, Journal of Organizational Behavior, 25, 527-545.

Lo, M.C. ve Ramayah, T. (2009). Dimensionality of organizational citizenship behavior (ocb) in a multicultural society: the case of Malaysia, International Business Research, 2(1), 48-55.

Mahmutoğlu, T., (2017). İş hayatında cinsel ayrımcılık ve örgütsel vatandaşlık davranışı üzerine etkileri, Yüksek Lisans Tezi, Hacettepe Üniversitesi, Sosyal Bilimler Enstitüsü, Ankara.

Mete, M. vd., (2015). Personel güçlendirme, örgütsel bağlılık ve iş memnuniyeti ilişkisinin yapısal eşitlik modeli ile incelenmesi: turizm sektöründe bir araştırma, Bartın Üniversitesi İktisadi ve İdari Bilimler Fakültes Dergisii, 6(12), 141-142.

Noori, M. ve Azma, F., (2013). Relationship between perceived empowerment by employees and organizational citizenship behavior (case study: public organizations in bojnourd), International Journal of Academic Research in Business and Social Sciencess, 3(8), 438-441.

Organ, D. ve Lingl, A. (1995). Personality, satisfaction and organizational citizenship behavior, The Journal of Social Psychology, 135(3), 339-350.

Pekküçükşen, Ş., (2013). Değişen yerel yönetim anlayışında insan kaynakları stratejilerinin geliştirilmesi (Konya Büyükşsehir Belediyesi Örneği), Doktora Tezi, Gazi Üniversitesi Sosyal Bilimler Enstitüsü, Ankara.

Podsakoff,P.M., Mackenzıe, S.B., Paıne, J.B. ve Bachrach, D.G. (2000). Organizational citizenship behaviors: a critical review of the theoretical and empirical literature and suggestions for future research, Jounal of Management, 26(3), 514-524.

Salihoğlu , G., (2013). Örgütsel bağlılık ve örgütsel vatandaşlık davranışı arasındaki ilişki (Çorum İlinde Hastane Çalışanlarına Anket Uygulaması), Sosyal ve Beşeri Bilimler Dergisi, 5(1), 303.

Spreitzer, G.M., (1995).Psychological empowerment in the workplace: dimensions, measurement and validation, Academy of Management Journal, 38(5),1443.

Spreitzer, G. vd., (1999). Empowered to lead: the role of psychological empowerment in leadership, Journal of Organizational Behavior, 20(4), 511-526.

Şanal, M., (2013). Örgütsel vatandaşlık davranışının işletmeler açısından önemi, Çukurova Üniversitesi Sosyal Bilimler Enstitüsü Dergisi, 22(1), 529-538.

Taşlıyan, M. vd., (2014). Personel güçlendirmenin örgütsel bağlılık ve örgütsel vatandaşlık davranışına etkisi: akademisyenler üzerine bir araştırma, Çankırı Karatekin Üniversitesi Sosyal Bilimler Enstitüsü Dergisi, 6(1), 326327.

Tolay, E., Sürgevil, O. ve Topoyan, M. (2012). Akademik çalışma ortamında yapısal ve psikolojik güçlendirmenin duygusal bağlılık ve iş doyumu üzerindeki etkileri, Ege Akademik Bakış, 12(4),449-465.

Turnipseed, D. (2002). Are good soldiers good? exploring the link between organization citizenship behavior and personal ethics , Journal of Business Research, 55, 1-15.

Ulusoy, H. ve Sarıçoban, S., (2017). Hekimlerin örgütsel vatandaşlık düzeylerinin kurumda çalışmaktan memnuniyet durumlarının ve kurumda kalma niyetlerinin incelenmesi, Uluslararası Sosyal Araştırmalar Dergisi, 10(48), 659668.

Wang, G. ve Lee, P.D. (2009). psychological empowerment and job satisfaction an analysis of interactive effects, Group \& Organization Management, 34(3),271-296.

Wat, D. ve Shaffer, M. A., (2005). Equity and relationship quality influences on organizational citizenship behaviors the mediating role of trust in the supervisor and empowerment, Personnel Review, 34 (4), 406-422.

Yatkın, A., (2009). Kamu yönetiminde bireysel performans ve örgütsel verimlilik aracı olarak personel güçlendirme, EJournal of New World Sciences Academy, 4(2), 128-141.

Yıldız, G., (2017). Örgüt kültürün özel ve devlet hastanelerinde görev yapan hemşirelerin örgütsel vatandaşlık davranışları üzerine etkisi ve bir uygulama, Yüksek Lisans Tezi, Aydın Üniversitesi Sosyal Bilimler Enstitüsü, İstanbul.

Yücel, İ. ve Demirel, Y., (2012). Psikolojik güçlendirmenin örgütsel vatandaşlık davranışına etkisi üzerine bir araştırma, Kocaeli Üniversitesi Sosyal Bilimler Enstitüsü Dergisi, 23,19-48. 